\title{
Removal of Basic Dyes from Aqueous Solutions by Adsorption onto Moroccan Clay (Fez City)
}

\author{
Zineb Bencheqroun ${ }^{1,3}$, Imane El Mrabet ${ }^{1}$, Mohammed Kachabi ${ }^{1}$, Mostafa Nawdali ${ }^{2}$, Isabel Neves ${ }^{3}$ and \\ Hicham Zaitan ${ }^{1, *}$ \\ ${ }^{1}$ Chemistry of Condenser Matter Laboratory (LCMC), Faculty of Science and Technology, Sidi Mohamed Ben \\ Abdellah University, B.P. 2202, Fez, Morocco \\ ${ }^{2}$ Chemistry of Condenser Matter Laboratory (LCMC), Faculty of Polydisciplinary, Sidi Mohamed Ben Abdellah \\ University, B.P 1223, Taza, Morocco \\ ${ }^{3}$ Center of Chemistry, Chemistry Department and CEB - Center of Biological Engineering, University of Minho, \\ 4710-057 Braga, Portugal
}

\begin{abstract}
The main objective of this study was to investigate the potential of natural clay obtained from Fez city, Morocco- as an adsorbent for the removal of basic dyes (Astrazon Blue BG and Astrazon Yellow 7GLL) from liquid effluents. Natural clay was characterised using different physical-chemical methods, including nitrogen adsorption-desorption isotherms, X-ray diffraction (XRD), scanning electron microscopy (SEM), Fourier transform infrared spectroscopy (FTIR), $\mathrm{pH}$ of the point of zero charge $\left(\mathrm{pH}_{\mathrm{PZC}}\right)$ and Boehm titration method. The clay was tested to remove various textile dyes from the aqueous solution at room temperature. Parameters such as initial dye concentration, solution $\mathrm{pH}$, adsorbent dosages and contact time were performed in a batch system for controlling the operating conditions. Experimental results indicated that the adsorption process is a fast and spontaneous reaction. A pseudo-second-order kinetic model provides the best fit to the experimental data of BG and YL adsorption onto the natural clay. The-adsorption isotherm data of both the dyes onto the natural clay were fitted well to the Langmuir model. A maximum monolayer adsorption capacity of 101 $\mathrm{mg} \cdot \mathrm{g}^{-1}$ for BG and $\quad 127 \mathrm{mg} \cdot \mathrm{g}^{-1}$ for YL are obtained at $298.15 \mathrm{~K}$.
\end{abstract}

The results suggest that the natural clay could be used as an inexpensive adsorbent for the removal of the textile dyes from aqueous solutions.

Keywords: Clay, Adsorption, Textile dyes, Langmuir, Freundlich.

\section{Introduction}

The world where we live everything is colorful, our clothes, our food our cosmetics, pharmaceuticals 1. These dyes are more and more synthetic dyes, because of their ease of synthesis, their rate of production and their large variety when compared to natural dyes ${ }^{2}$. Dyes can be classified according to their charge (anionic, cationic and non-ionic). Basic dyes are widely used in the dyeing industries of acrylic, silk-based nylon and wool ${ }^{3,4}$. These industries also create serious problems that lead to the deterioration of human health and the environment by discharging large amounts of pollutants into water sources without any previous treatment ${ }^{5}$. To solve this problem, ecological, economical, technical and simple processes to remove these pollutants from wastewater are urgently needed ${ }^{6}$.

* Corresponding author: Hicham Zaitan

Email address: hicham.zaitan@usmba.ac.ma

DOI: http://dx.doi.org/10.13171/mjc8319050803hz
Various treatment processes (physical, chemical and biological) such as adsorption, oxidation, coagulation and flocculation, filtration and adsorption are being used in order to mitigate the problem of water pollution by dyes in the environment $^{7,8}$.

Adsorption on activated carbon is considered to be an effective and attractive process for the application in wastewater treatment contaminated with dyes ${ }^{9}$. However, its use is restricted due to higher operating cost and safety concerns 10,11,12. Hence, more effective and economical viable technologies are required for the color removal from textiles effluent.

In this context, natural clay materials could be an attractive alternative for the adsorption of various pollutants from wastewater due to their low cost, high porosity, thermal stability, high cation exchange capacity, abundance and high adsorption capacity $^{8,11,13,17}$. 
Astrazon Blue BG (BG) and Astrazon Yellow 7GLL (YL) were chosen as basic dyes to test the effectiveness of natural clay. BG and YL are widely used for dyeing acrylic fibers.

This study aims to evaluate the potential use of natural clay from the region of $\mathrm{Fez}$, Morocco (namely CF) as a low-cost adsorbent for BG and YL dyes removal from aqueous solutions. The physicochemical and morphological properties of the natural clay were characterized. The effect of different physical-chemical parameters such as contact time, solution $\mathrm{pH}, \mathrm{CF}$ dose and initial dye concentration on the adsorption of $\mathrm{BG}$ and YL were evaluated. Additionally, kinetic and equilibrium models are applied to experimental data, and the best models are selected.

\section{Materials and methods}

\section{Materials}

Natural clay was obtained from deposits located in the city of Fez (Morocco) and used without any prior activation. Samples were ground and sieved to obtain particle sizes $(60-100 \mu \mathrm{m})$ and washed with distilled water. After that, dried at $383.15 \mathrm{~K}$ for $24 \mathrm{~h}$ and stored in hermetic plastic bottles until further use.

Two different commercial dyes (Astrazon Blue BG and Astrazon Yellow 7 GLL) were chosen as a model of basic dyes for adsorption experiments. They were obtained from the DyeStar society and were used without any further purification. Properties of these dyes are summarized in Table 1

Table 1. Some properties of BG and YL dyes.

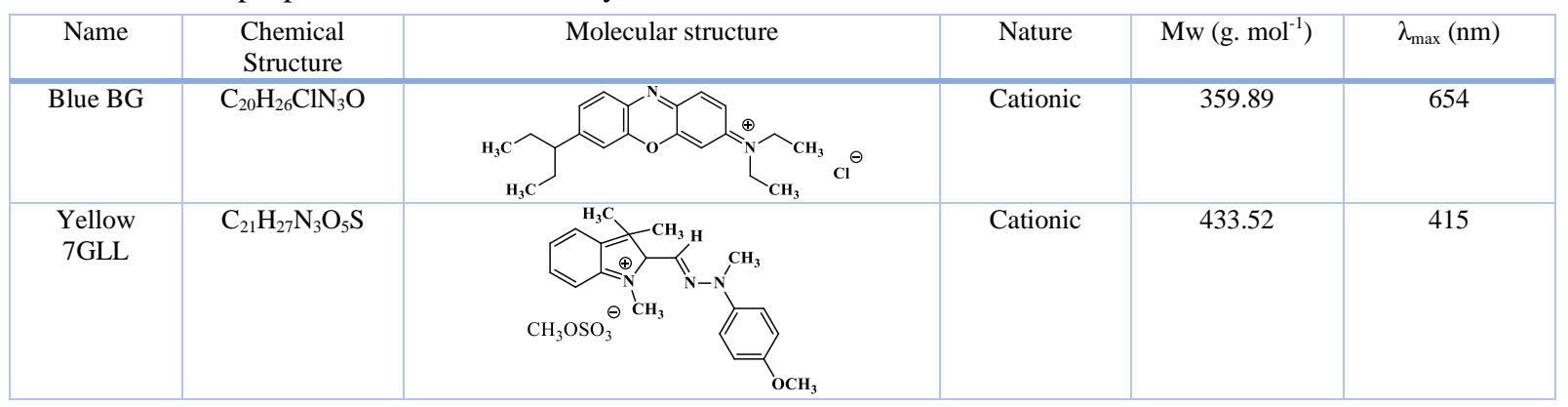

\section{Characterization of the adsorbent}

Specific surface area and pore volume of the natural clay (CF) was determined from $\mathrm{N}_{2}$ adsorption-desorption isotherms at $77 \mathrm{~K}$ using a Micromeritics Asap 2010 sorptometer (Micromeritics Corporate Headquarters, U.S.A). Sample of natural clay was degassed before analysis at $383.15 \mathrm{~K}$ for $10 \mathrm{~h}$ under vacuum at $<10^{-2} \mathrm{~Pa}$, in order to remove all physically adsorbed water molecules and small organic impurities. Chemical surface composition of the adsorbent before adsorption of BG and YL was identified by Fourier Transform Infrared Spectroscopy (FTIR) using a VERTEX70 spectrophotometer (Bruker Optics S.A.R.L., France) within the range of $4000-400 \mathrm{~cm}^{-}$ 1. The clay was previously characterized by X-ray diffraction (XRD, Philips Analytical X-Ray PW1710 diffractometer). Morphological features of CF were analyzed by scanning electron microscopy (SEM, Phenom ProX with EDS detector (Phenom-World BV, Netherlands).

The number of basic and acid surface in the $\mathrm{CF}$ adsorbent was determined using the Boehm's titration method ${ }^{6}$. A mass of $1.5 \mathrm{~g}$ clay sample was placed in contact with $40 \mathrm{~mL}$ of the following solutions: $\mathrm{NaOH}(0.1 \mathrm{M})$ and $\mathrm{HCl}(0.1 \mathrm{M})$. After that, the vials were sealed and stirred at $150 \mathrm{rpm}$ for $72 \mathrm{~h}$. The resulting solution was filtered, and then the excess of base or acid was titrated with against a standard hydrochloric acid solution $(0.1 \mathrm{M})$ or sodium hydroxide solution $(0.1 \mathrm{M})$. The numbers of moles of acidic sites were determined under the assumption that sodium hydroxide neutralizes acidic functional sites of different strength (strong, mild and weak acidic sites) on the surface of that $1.5 \mathrm{~g}$ of the $\mathrm{CF}$ adsorbent. The number of moles of basic sites was calculated from the amount of hydrochloric acid consumed by the natural clay.

The $\mathrm{pH}$ solution value required to give a zero surface charge $\left(\mathrm{pH}_{\mathrm{PZC}}\right)$ was determined through the procedure described by Noh and Schwarz ${ }^{7}$. Briefly, a series of solutions $(50 \mathrm{~mL}$ of $0.1 \mathrm{M} \mathrm{NaCl})$ were prepared, and their $\mathrm{pH}$ was adjusted to given a value between 2 and 12 by adding $\mathrm{NaOH} / \mathrm{HCl}$ solutions. Then, $0.1 \mathrm{~g}$ of the adsorbent sample was added to each $50 \mathrm{~mL}$ of $\mathrm{NaCl}$ solution. Nitrogen was bubbled through the solutions. The suspensions were then shaken for $72 \mathrm{~h}$ at room temperature and the equilibrium $\mathrm{pH}$ of the solutions was then measured using a $\mathrm{pH}$-meter. The $\mathrm{pH}_{\mathrm{pzc}}$ is the point where $\mathrm{pH}_{\text {final }}=\mathrm{pH}_{\text {initial }}$.

\section{Batch adsorption experiments}

The adsorption experiments were carried out in closed flasks using a Batch method. A $0.01 \mathrm{~g}$ mass of natural clay was dispersed in a $20 \mathrm{~mL}$ solution of the $\mathrm{BG}$ and YL stained solution with an initial concentration varying from 0 to $500 \mathrm{mg}$. $\mathrm{L}^{-1}$ without 
pH adjustment. The mixture was shaken $(\sim 200 \mathrm{rpm})$ until the equilibrium was reached then the separation of the two phases was achieved by centrifugation at $5000 \mathrm{rpm}$ for $5 \mathrm{~min}$. Finally, the equilibrium BG and
YL dyes concentrations were determined using a Shimadzu UV/2501 UV-Vis spectrophotometry corresponding to $\lambda_{\max }$ of each dye: $654 \mathrm{~nm}$ and

$415 \mathrm{~nm}$ for BG and YL, respectively (Figure 1).

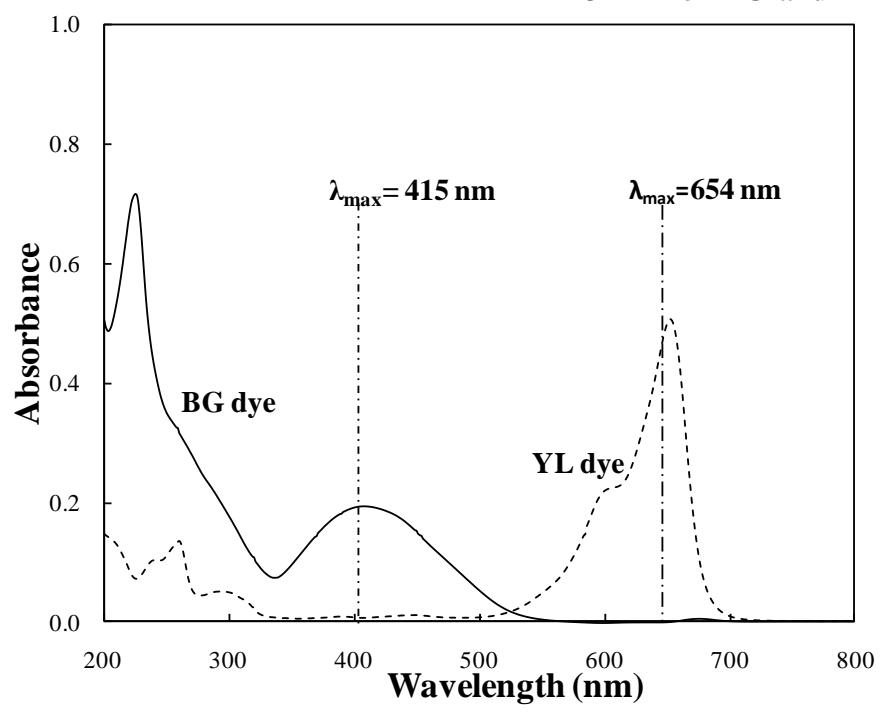

Figure 1. Typical UV-vis spectrum of every single solution of BG and YL

Amounts of BG and YL adsorbed per unit mass of clay (q, mg.g $\mathrm{g}^{-1}$ ) were calculated using the following equation:

$q_{t, e}=\frac{\left(C_{0}-C_{t, e}\right) \cdot V}{W}$

Eq. 1

Where $\mathrm{C}_{0}\left(\mathrm{mg} . \mathrm{L}^{-1}\right)$ and $\mathrm{C}_{\mathrm{t}, \mathrm{e}}\left(\mathrm{mg} . \mathrm{L}^{-1}\right)$ are the initial and the equilibrium or at a specific time concentration of dye, respectively. $\mathrm{W}(\mathrm{g})$ is the mass of the adsorbent and $\mathrm{V}(\mathrm{L})$ is the volume of liquid.

The effect of operating conditions (initial dye concentration, solution $\mathrm{pH}$, adsorbent dose and contact time) on the adsorption of dye onto CF was investigated in a batch system at room temperature. All tests were performed in triplicates.

\section{Results and Discussion}

\section{Characterization of natural Clay}

The nitrogen adsorption-desorption isotherm of natural clay was represented in Fig. 2. It is shown that the isotherm of the CF clay studied follows the type IV according to the IUPAC classification with apparent a hysteresis loop in the $\mathrm{P} / \mathrm{P}_{0}$ range of 0.45-1.0.

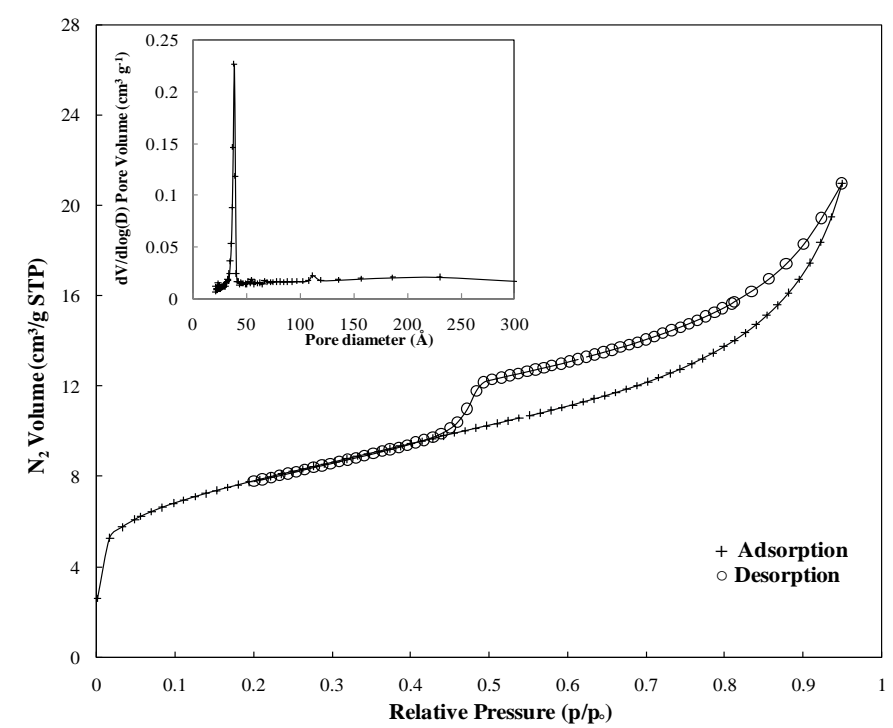

Figure 2. Nitrogen adsorption and desorption isotherms at $77 \mathrm{~K}$ (a) and pore size distribution of CF

The CF clay is essentially mesoporous structure formed between the elementary clay structures that are called tactoids with the average diameter is about
$3.8 \mathrm{~nm}$. The specific clay surface area is $28 \mathrm{~m}^{2} \cdot \mathrm{g}^{-1}$, with a total pore volume determined from the amount adsorbed at $\mathrm{P} / \mathrm{P}_{0}=0.99$ equals $0.033 \mathrm{~cm}^{3} \cdot \mathrm{g}^{-1}$. 
Figure 3 shows the XRD diffractogram of the CF clay, which shows the mineralogical composition of clay where it can be concluded that the CF clay is mainly composed of quartz (Q) associated with calcite (C). For the preparation of this diffractogram, a clay fraction smaller than $2 \mu \mathrm{m}$ was analyzed, the clay was subjected to a different treatment.

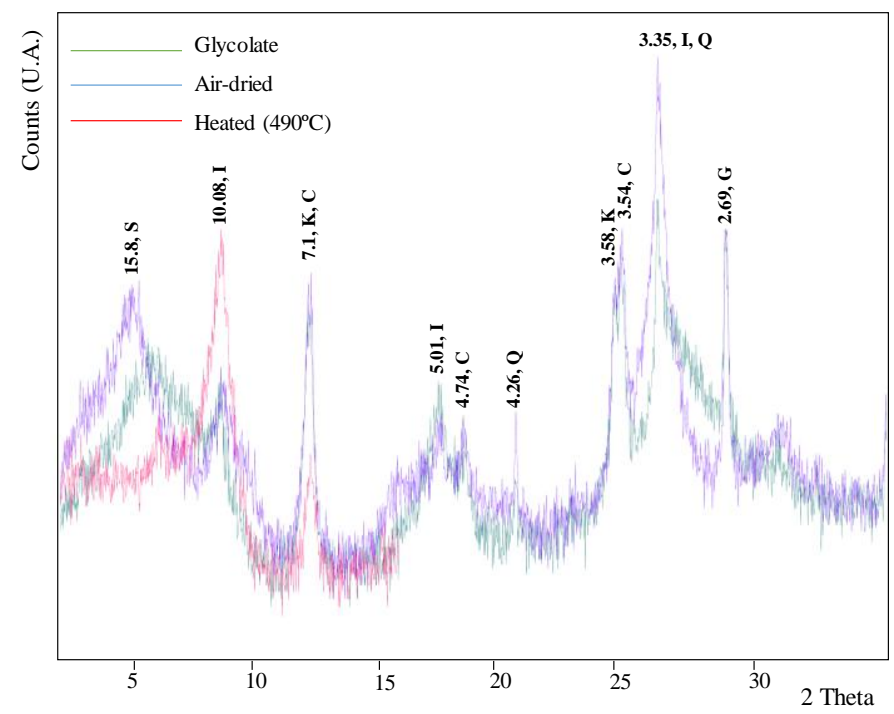

Figure 3. XRD patterns of < $2 \mu \mathrm{m}$ of fraction from CF Clay: Q - Quartz; C - Chlorite; I - Illite; S - Smectite; $\mathrm{Ca}$-Calcite; $\mathrm{K}$ - Kaolinite, $\mathrm{G}$ - Goethite

From this XRD patterns (Fig. 3), it is can also estimate the amounts of the minerals in the studied clay. A semi-quantitative amount of the mineral is shown in Table 2 and followed the order: Calcite> Kaolinite>Smectite> Chlorite> Illite> Goethite> Quartz.

Table 2. Semi-quantitative amount of the minerals in the CF clay (in \%).

\begin{tabular}{|c|c|c|c|c|c|c|c|}
\hline & Quartz & Chlorite & Illite & Smectite & Calcite & Kaolinite & Goethite \\
\hline $\begin{array}{c}\text { Mineralogical } \\
\text { composition total (\%) }\end{array}$ & 4 & 7 & 6 & 12 & 43 & 24 & 4 \\
\hline
\end{tabular}

The energy-dispersive X-Ray Spectroscopy (EDX spectrum) (Fig. 4) obtained, shows the

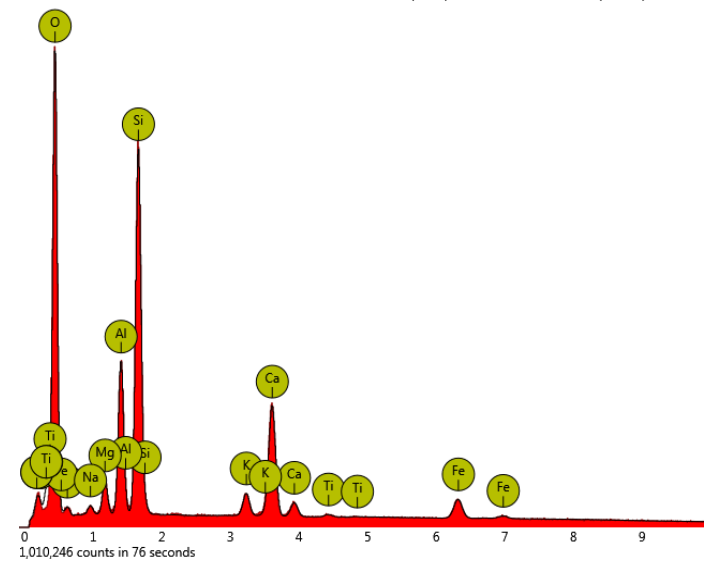

Figure 4. EDX spectra of CF clay
The SEM technique is used to obtain information concerning the morphology and the chemical composition of the $\mathrm{CF}$ adsorbent. According to the presence of metals, such as aluminum (Al), silicon $(\mathrm{Si})$, calcium $(\mathrm{Ca})$, iron $(\mathrm{Fe})$, and magnesium $(\mathrm{Mg})$.
SEM, it is observed that the clay is composed of small particles and aggregates of particles, with varying dimensions (Fig. 5). 

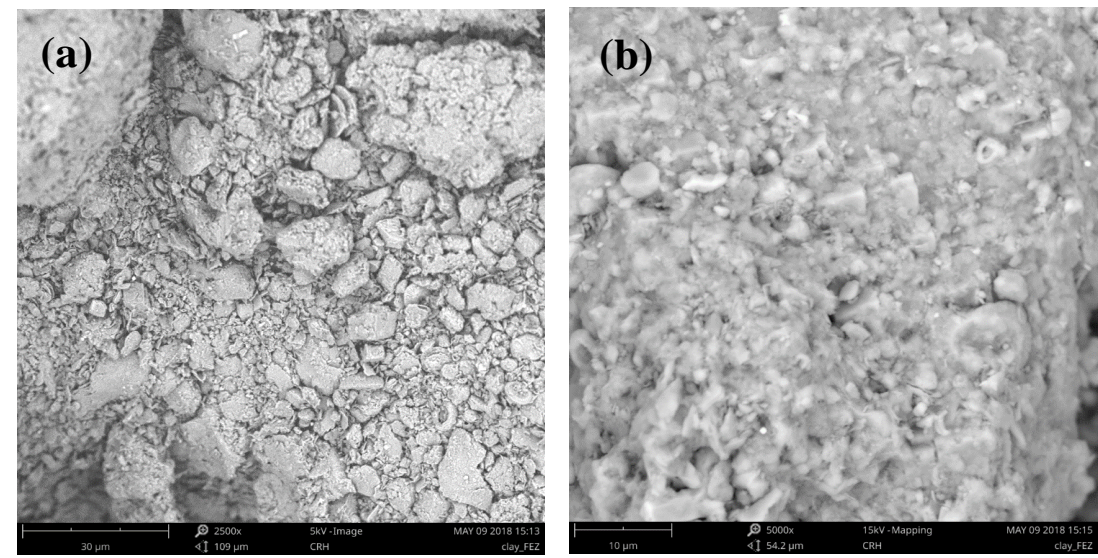

Figure 5. SEM micrographs of CF clay with different resolutions (a) 2500x and (b) 5000x.

Figure 6 illustrated the FTIR spectrum of CF clay and adsorbed $\mathrm{CF}$ with BG and YL dyes. Figure 6 shows a distinct absorption bands between 3700 to $3400 \mathrm{~cm}^{-1}$ corresponding to the elongation vibrations of the hydroxyl groups that occupy the surface of the octahedral and tetrahedral sites of layers of CF clay.

The bands observed at 3411 to $1656 \mathrm{~cm}^{-1}$ were additional bands that were associated with $\mathrm{H}-\mathrm{O}-\mathrm{H}$ vibrations of free water molecules. It should be noted that the stretching bands near 1433 and $898 \mathrm{~cm}^{-1}$ may be due to the existence of calcite in agreement with those results obtained by XRD analysis. The CF clay has spectral bands in the range 1200 to $650 \mathrm{~cm}^{-1}$ attributed to the vibrations of the $\mathrm{Si}-\mathrm{O}-\mathrm{Si}, \mathrm{Al}-\mathrm{OH}$ and $\mathrm{Si}-\mathrm{O}-\mathrm{Al}$ groups located on the surface of the layered clay minerals. Maximum absorption of silicate minerals was observed at $1000 \mathrm{~cm}^{-1}$ while bands at $528 \mathrm{~cm}^{-1}$ could be to $\mathrm{Al}-\mathrm{O}-\mathrm{Si}$ and $\mathrm{Si}-\mathrm{O}-\mathrm{Si}$ bending vibrations.

After adsorption of BG and YL molecules dyes onto $\mathrm{CF}$, a shifting of the peaks is observed to 700 and $800 \mathrm{~cm}^{-1}$. Similar effects can be observed for the $\mathrm{Si}-$ $\mathrm{OH}$ vibration at 3700 and $3400 \mathrm{~cm}^{-1}$.

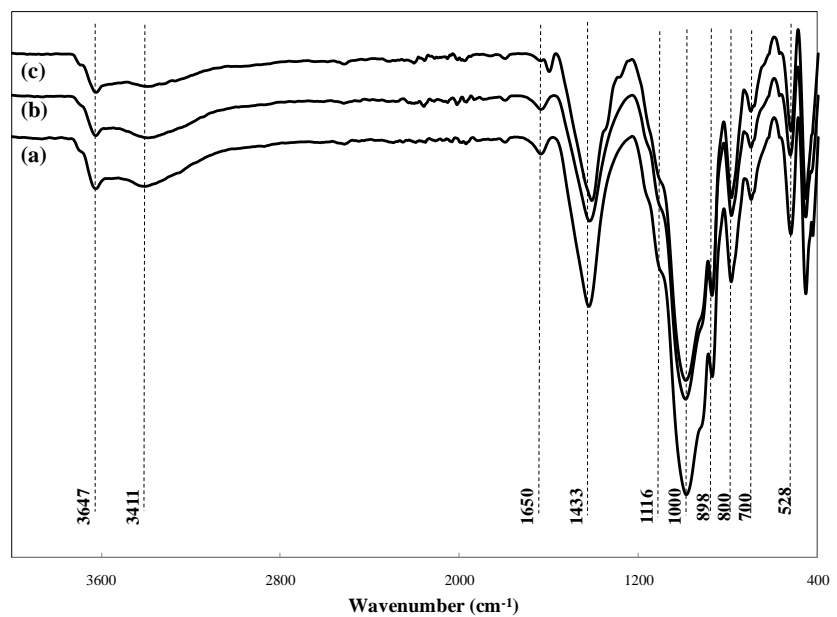

Figure 6. FTIR spectra: a) raw CF clay, b) CF loaded with YL molecules, and c) CF loaded with BG molecules

The Boehm method permitted us to determine the chemical groups to be present on the clay surface. Results present on Table 3 to lead to determine that the quantity of the basic groups is significantly greater than that acidic groups, which is consistent with the FTIR analysis and also the previously measured $\mathrm{pH}_{\mathrm{PZC}}$ value $\left(\mathrm{pH}_{\mathrm{PZC}}=9.0\right)$. This can be said that when the $\mathrm{pH}$ of the solution is higher than the $\mathrm{pH}_{\mathrm{PZC}}\left(\mathrm{pH}>\mathrm{pH}_{\mathrm{PZC}}\right)$ the clay surface is negatively charged and vice versa when the $\mathrm{pH}$ is lower than $\mathrm{pH}_{\mathrm{PZC}} \quad\left(\mathrm{pH}<\mathrm{pH}_{\mathrm{PZC}}\right)$ the positively charged sites dominate on the surface of the clay adsorbent.

Table 3. Chemical groups on the surface of natural clay.

\begin{tabular}{|c|c|c|}
\hline $\begin{array}{c}\text { Total acid groups } \\
\left(\text { meq. } \mathrm{L}^{-1}\right)\end{array}$ & $\begin{array}{c}\text { Total basic groups } \\
\left(\text { meq. } \mathrm{L}^{-1}\right)\end{array}$ & $\begin{array}{c}\text { Total groups } \\
\left(\text { meq. } \mathrm{L}^{-1}\right)\end{array}$ \\
\hline 0.320 & 2.667 & 2.987 \\
\hline
\end{tabular}

Effect of the adsorbent dose
Figure 7 shows the effect of the adsorbent mass on the adsorption capacity of CF clay and removal efficiency towards BG and YL dyes. Experiments 
were carried out in the range 0.1-0.6 $\mathrm{g}$ of $\mathrm{CF}$ at room temperature using a total volume of $20 \mathrm{~mL}$ of $\mathrm{BG}$ and YL solution with an initial concentration of $300 \mathrm{mg} . \mathrm{L}^{-1}$ without $\mathrm{pH}$ adjustment, during $3 \mathrm{~h}$ of contact time.

Figure 7 shows that the removal efficiency of BG and YL dyes is increased with the increase of adsorbent mass up to a certain point after that point the removal efficiency remained almost constant. It can be clearly depicted from the figure that the efficiency of BG is increased from $78 \%$ to $97 \%$ with an increase in the adsorbent mass from 0.025 to $0.1 \mathrm{~g}$ and the efficiency of YL is increased from 76 to 99 $\%$ with an increase in the adsorbent mass from 0.025 to $0.1 \mathrm{~g}$ and the optimal $\mathrm{CF}$ dose to achieve equilibrium is $0.1 \mathrm{~g}$ correspond to $5 \mathrm{~g} . \mathrm{L}^{-1}$. Thus, the increase of the adsorbent mass leads to an increase in the number of available adsorption sites which favors the increase of the adsorption capacity.

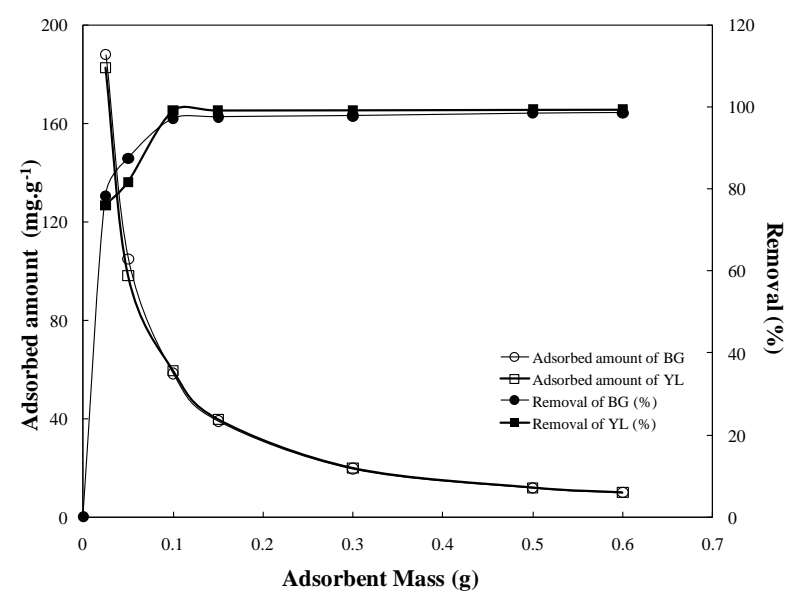

Figure 7. Effect of adsorbent mass on BG and YL removal (Initial conc.: $300 \mathrm{mg} \mathrm{L}^{-1}$, contact time $=3 \mathrm{~h}$, agitation speed $=200 \mathrm{rpm}$ and $\mathrm{T}=298.15 \mathrm{~K}$ )

\section{Effect of initial pH}

The effect of the initial $\mathrm{pH}$ of the solution (range 2-12) on the adsorption of BG and YL dyes onto CF clay was studied and presented in Figure 8. As shown in Figure 8, the adsorbed amounts of BG and YL onto CF clay-increased 49 to $60 \mathrm{mg} \cdot \mathrm{g}^{-1}$ for $\mathrm{BG}$ and 42 to $60 \mathrm{mg} \cdot \mathrm{g}^{-1}$ for $\mathrm{YL}$ when $\mathrm{pH}$ of the solution increased from 2 to 12 .

As the solution became basic $\left(\mathrm{pH}>\mathrm{PH}_{\mathrm{PZC}}\right)$, the clay surface is negatively charged due to the deprotonation of the surface hydroxyl site $(\mathrm{Si}-\mathrm{OH}$ and $\mathrm{Al}-\mathrm{OH}$ ) which leads to an electrostatic (columbic) attraction between the sites on the surface and the positively charged BG and YL. Moreover, an electrostatic attraction between BG and YL dyes and the positive charge on the surface of $\mathrm{CF}$ at low $\mathrm{pH}$ is evident

Consequently, the mechanism proposed can be described in Eqs. 2 and 3.

$$
\begin{array}{lr}
\mathrm{Si}-\mathrm{OH}+{ }^{-} \mathrm{OH} \leftrightarrow \mathrm{Si}-\mathrm{O}^{-}+\mathrm{H}_{2} \mathrm{O} & \text { Eq. } 2 \\
\mathrm{Si}-\mathrm{O}^{-}+\mathrm{BG}^{+} \text {or } \mathrm{YL}^{+} \leftrightarrow \mathrm{Si}^{-} \mathrm{O}^{-+} \mathrm{BG}^{-} \mathrm{Si}-\mathrm{O}^{-+}{ }^{+} \mathrm{YL} & \text { Eq. } 3
\end{array}
$$

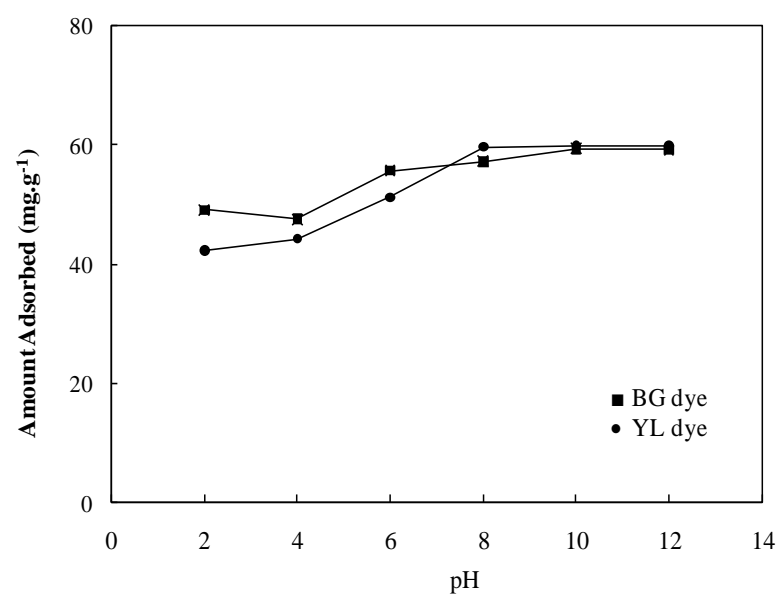

Figure 8. Effect of $\mathrm{pH}$ on the adsorption of $\mathrm{BG}$ and YL onto $\mathrm{CF}$ clay. (Initial conc.: $300 \mathrm{mg} \mathrm{L}^{-1}$, contact time= $4 \mathrm{~h}, \mathrm{~m}=0.05 \mathrm{~g}$, agitation speed $=200 \mathrm{rpm}$ and $\mathrm{T}=298.15 \mathrm{~K})$.

\section{Adsorption Kinetics}

The effect of contact time on the removal of BG and YL dyes is investigated. Adsorption experiments were carried at different time intervals, keeping constant the volume $(\mathrm{V}=200 \mathrm{~mL})$, the initial dye 
concentration $\left(\mathrm{C}_{0}=300 \mathrm{mg} \mathrm{L}^{-1}\right)$ at room temperature and applying a dose of CF clay of $1 \mathrm{~g}$.

Adsorption kinetics of BG and YL dyes by natural clay are illustrated in Figure 9. Results obtained indicate that the removal of the two cationic dyes (BG and YL) was rapid in the first process period between 5 to $10 \mathrm{~min}$, which may be due to the presence, at beginning, of a large number of vacant sites ( $\mathrm{Si}-\mathrm{OH}$ silanol and $\mathrm{Al}-\mathrm{OH}$ aluminol groups) that are available for the adsorption of $\mathrm{BG}$ and $\mathrm{YL}$ molecules. After that, the adsorption rate decreased and then reached equilibrium value at $\sim 30 \mathrm{~min}$ for BG and YL dye, with an elimination which are equal to $86 \%$ and $96 \%$ for-BG and YL dyes, respectively, indicating the decrease in the number of adsorption sites accessible to interact with the residual dye molecules.

In order to characterize the kinetics involved in the adsorption process of the pseudo first order and pseudo second order equations have been proposed 18,19 . The Pseudo first order model is given by equation 4:

$q_{t}=q_{e}\left(1-e^{-k_{1} t}\right)$

Eq. 4 where $\mathrm{q}_{\mathrm{t}}$ and $\mathrm{q}_{\mathrm{e}}$ are respectively the adsorption capacity at time $\mathrm{t}$ and equilibrium time, and $\mathrm{k}_{1}$ is the flow constant of the Pseudo-First-Order model.

The Pseudo second order equation is presented by equation 5 below:

$q_{t}=\frac{k_{2} q_{e}^{2} t}{1+k_{2} q_{e} t}$

Eq. 5

Where $\mathrm{k}_{2}\left(\mathrm{~g} \cdot \mathrm{mg}^{-1} \cdot \mathrm{min}^{-1}\right)$ is the adsorption rate constant for the pseudo-second-order kinetic model. The model fitting was evaluated from the determination coefficient $\left(\mathrm{R}^{2}\right)$. The pseudo-secondorder kinetic model was more suitable for an explanation of $\mathrm{BG}$ and YL dyes adsorption process mechanism, due to the highest value of correlation coefficient rather $\left(\mathrm{R}^{2}>0.98\right)$ than to pseudo-first-order kinetic models (see the Table 4).

Also, the values for the adsorption amounts $\left(\mathrm{q}_{\mathrm{e}}\right)$ determined using the Pseudo-second-order kinetic model are more in agreement with the $\mathrm{q}_{\exp }$ experimental values than those obtained with the pseudo-first-order model. Then, the application of this model suggests that chemical interactions are responsible for the adsorption of $\mathrm{BG}$ and YL by the $\mathrm{CF}$ natural

clay.

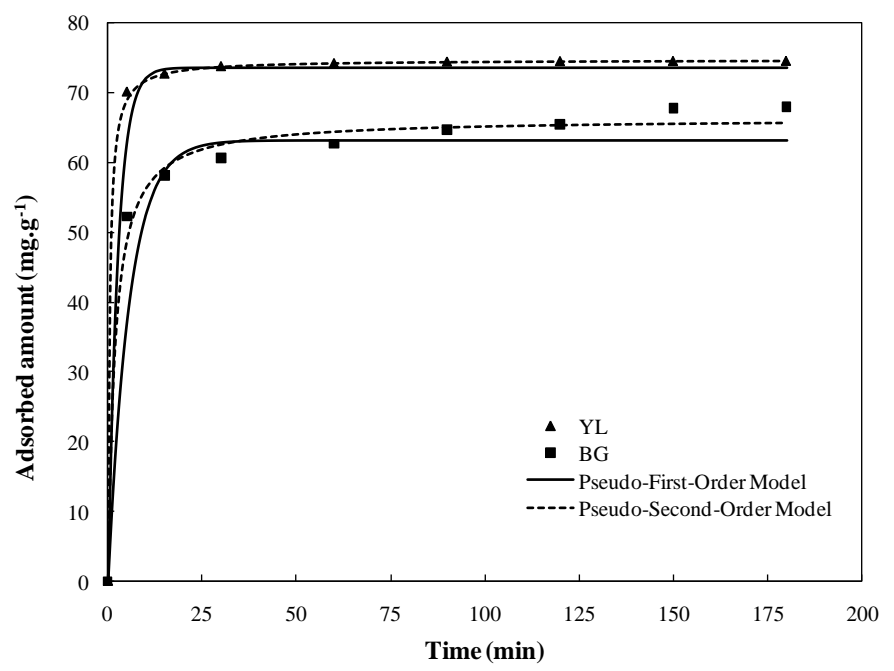

Figure 9. Effect of contact time on the adsorption of BG and YL onto natural clay (Experimental conditions: Initial conc.: $300 \mathrm{mg} \cdot \mathrm{L}^{-1}$, contact time $=3 \mathrm{~h}, \mathrm{~m}=1 \mathrm{~g}$, agitation speed $=200 \mathrm{rpm}$ and $\mathrm{T}=298.15 \mathrm{~K}$ )

Table 4. Kinetic model parameters of BG and YL dyes adsorption onto CF clay.

\begin{tabular}{|l|c|c|c|}
\hline Kinetic model & Parameters & BG & YL \\
\hline Pseudo-first-order & $\mathrm{q}_{\exp }\left(\mathrm{mg} \cdot \mathrm{g}^{-1}\right)$ & 68 & 75 \\
\cline { 2 - 4 } & $\mathrm{q}_{\mathrm{e}}\left(\mathrm{mg}^{-1}\right)$ & 63.1 & 73.5 \\
\cline { 2 - 4 } & $\mathrm{k}_{1}\left(\mathrm{~min}^{-1}\right)$ & 0.18 & 0.387 \\
\hline \multirow{3}{*}{ Pseudo-second-order } & $\mathrm{R}^{2}$ & 0.94 & 0.97 \\
\hline & $\mathrm{q}_{\exp }\left(\mathrm{mg} \cdot \mathrm{g}^{-1}\right)$ & 67 & 74.5 \\
\hline & $\mathrm{q}_{\mathrm{e}}\left(\mathrm{mg}^{-1}\right)$ & 66.22 & 0.032 \\
\hline & $\mathrm{k}_{2}\left(\mathrm{~g} \cdot \mathrm{mg}^{-1} \cdot \mathrm{min}^{-1}\right)$ & 0.0084 & 0.99 \\
\hline
\end{tabular}

\section{Adsorption isotherms}

The adsorption isotherms were on which the adsorption capacity of clay for BG and YL dyes was conducted. The experimental isotherms for the adsorption of BG and YL onto CF clay are presented in Figure 10. 
The Langmuir and Freundlich models were applied to fit the experimental equilibrium adsorption data. The mathematical expression for Freundlich and Langmuir models are described by the following equation ${ }^{20,21}$ :

$q_{\mathrm{e}}=\frac{q_{\mathrm{m}} K_{\mathrm{L}} C_{\mathrm{e}}}{1+K_{\mathrm{L}} C_{\mathrm{e}}}$

Eq. 6

$q_{\mathrm{e}}=K_{\mathrm{F}} C_{e}^{1 / n}$

Eq. 7
Where $\mathrm{K}_{\mathrm{L}}\left(\mathrm{L}_{\mathrm{mgg}}{ }^{-1}\right)$ is the Langmuir constant related to the energy of adsorption. $\mathrm{q}_{\mathrm{m}}$ and $\mathrm{q}_{\mathrm{e}}$ (mg.g${ }^{1}$ ) are the maximum and the equilibrium adsorption capacities of the Langmuir model, respectively. $\mathrm{C}_{\mathrm{e}}$ (mg. $\mathrm{L}^{-1}$ ) is the equilibrium concentration of the adsorbate. $\mathrm{K}_{\mathrm{F}}\left(\mathrm{L} \cdot \mathrm{mg}^{-1}\right)$ is the Freundlich constant and $1 / \mathrm{n}$ is the heterogeneity factor.

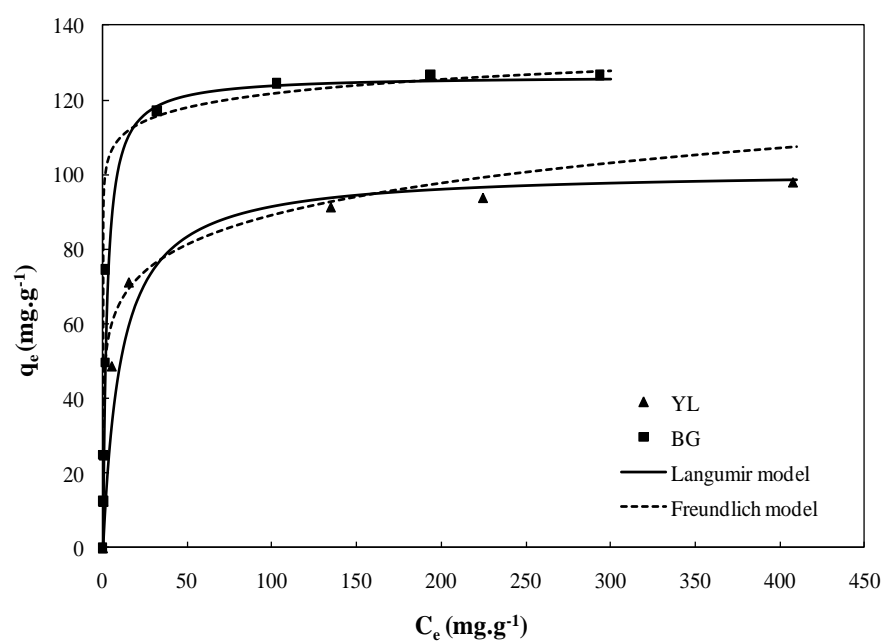

Figure 10. Equilibrium data of $B G$ and $Y L$ adsorption onto natural clay (Experimental conditions: contact time $=3 \mathrm{~h}, \mathrm{~m}=0.01 \mathrm{~g}$, agitation speed $=200 \mathrm{rpm}$ and $\mathrm{T}=298.15 \mathrm{~K}$ )

The resulting isotherms of $\mathrm{BG}$ and $\mathrm{YL}$ dyes (Fig. 10) prove that CF clay has a high affinity toward $\mathrm{BG}$ and $\mathrm{YL}$ cationic dyes. According to Fig. 10 , it is noticed that the CF clay is effective in removing dye at low equilibrium concentrations and reached the maximum adsorption capacity at highest concentrations.

The values of isotherm parameters, the maximum adsorption capacity $\left(\mathrm{q}_{\mathrm{m}}\right)$ and the linear regression coefficients $\left(\mathrm{R}^{2}\right)$ estimated by non-linear regression method are given in Table 5. It can be seen from Fig. 10 that the better adjustment of the experimental data was performed by the Langmuir model, indicating that the adsorption process of $\mathrm{BG}$ and $\mathrm{YL}$ on $\mathrm{CF}$ clay takes place as monolayer adsorption on independent sites of the same nature. This is also confirmed by the high value of $\mathrm{R}^{2}$ in case of Langmuir compared to Freundlich. The maximum adsorption capacity of BG and YL determined from the Langmuir model was 101 and $127 \mathrm{mg} . \mathrm{g}^{-1}$ respectively. The results showed that the adsorption capacities of these cationic dyes were relatively large.

Table 5. Isotherm constant parameters and correlation coefficients calculated for BG and YL adsorption-on natural clay.

\begin{tabular}{|c|l|c|c|}
\hline Model & \multicolumn{1}{|c|}{ Parameters } & BG & YL \\
\hline \multirow{3}{*}{ Langmuir } & $\mathrm{q}_{\mathrm{m}}\left(\mathrm{mg} \cdot \mathrm{g}^{-1}\right)$ & 101 & 127 \\
\cline { 2 - 4 } & $\mathrm{K}_{\mathrm{L}}\left(\mathrm{L} \cdot \mathrm{g}^{-1}\right)$ & 0.094 & 0.45 \\
\cline { 2 - 4 } & $\mathrm{R}^{2}$ & 0.98 & 0.97 \\
\hline \multirow{3}{*}{ Freundlich } & $\mathrm{K}_{\mathrm{F}}\left(\left(\mathrm{mg} \cdot \mathrm{g}^{-1}\right)\left(\mathrm{L}_{\mathrm{m}} \mathrm{mg}^{-1}\right)^{1 / \mathrm{n}}\right)$ & 48.5 & 99.5 \\
\cline { 2 - 4 } & $\mathrm{n}$ & 0.13 & 0.044 \\
\cline { 2 - 4 } & $\mathrm{R}^{2}$ & 0.93 & 0.85 \\
\hline
\end{tabular}

The maximum adsorption capacity of the CF clay for BG and YL was compared with those reported in the literature for different adsorbents (see Table 6).

As it can be seen in Table 6, the maximum adsorption capacities of BG and YL onto CF clay are even higher of those reported values in the literature: silica, Macroalga C. lentillifera, Wheat bran, clinoptilolite, smectite rich natural clays but lower than the values reported for, sepiolite, montmorillonite and Fly ash. 
Table 6. Maximum adsorption capacities of different adsorbents used for the removal of BG and YL dyes.

\begin{tabular}{|l|c|c|c|}
\hline Biosorbent & Dyes & q $\left(\mathrm{mg} \cdot \mathrm{g}^{-1}\right)$ & References \\
\hline CF clay & BG & 101 & This study \\
\hline Silica & BG & 11 & 22 \\
\hline Macroalga C. lentillifera & BG & 49.26 & 23 \\
\hline Sepiolite & BG & 155.5 & 24 \\
\hline Fly ash & BG & 128.2 & This study \\
\hline CF clay & YL & 127 & 25 \\
\hline Montmorillonite & YL & 434.2 & 26 \\
\hline Wheat bran & YL & 69.09 & 27 \\
\hline Smectite rich natural clays & YL & 76.92 & 28 \\
\hline Clinoptilolite & YL & 59.6 & 29 \\
\hline Bentonite & YL & 256.4 & 30 \\
\hline Sepiolite & YL & 30.62 & \\
\hline
\end{tabular}

\section{Conclusion}

The present work demonstrates that natural clay can be used as an inexpensive and readily available alternative adsorbent capable of removing cationic dyes in wastewater treatment. Experimental data showed that adsorption capacities were influenced by factors such as contact time, dye concentrations and $\mathrm{pH}$ value. The adsorption equilibrium was explained by the Langmuir isotherm while the adsorption kinetic followed the Pseudo-second-order model. Therefore, the CF clay used in this study has good potential to be used as an adsorbent in terms of performance and lower cost for the removal of toxics dyes from industrial wastewater.

\section{Acknowledgement}

Z. Bencheqroun is grateful for her Erasmus grant. Authors are also Prof. Teresa Valente for help in the XRD analysis. This work has been developed under the scope of the projects: BioTecNorte (operation NORTE-01-0145-FEDER-000004),

PTDC/AAGTEC/5269/2014 and Centre of Chemistry (UID/QUI/00686/2013 and UID/QUI/0686/2016).

\section{References}

1- D. Pokhrel, T. Viraraghavan, Treatment of pulp and paper mill wastewater - a review, Sci.

Total Environ., 2004, 333, 37-58.

2- S. Mondal, Methods of Dye Removal from Dye House Effluent-An Overview, Environ. Eng. Sci., 2008, 25, 383-396.

3- J. E. Aguiar, J.A. Cecilia, P.A.S. Tavares, D.C.S. Azevedo, E. Rodríguez Castellón, S.M.P. Lucena, I.J. Silva Junior, Adsorption study of reactive dyes onto porous clay heterostructures, Appl. Clay Sci., 2017, 135, 35-44.

4- E. N. El Qada, S. J. Allen, G. M. Walker, Adsorption of basic dyes from aqueous solution onto activated carbons, Chem. Eng. J., 2008, 135, 174-184.

5- J. N. Tiwari, K. Mahesh, N.H. Le, K.C. Kemp, R. Timilsina, R.N. Tiwari, K.S. Kim, Reduced graphene oxide-based hydrogels for the efficient capture of dye pollutants from aqueous solutions, Carbon N. Y., 2013, 56, 173-182.

6- A. Rahman, T. Urabe, N. Kishimoto, Color Removal of Reactive Procion Dyes by Clay Adsorbents, Procedia Environ. Sci., 2013, 17, 270-278.

7- J. Labanda, J. Sabaté, J. Llorens, Modeling of the dynamic adsorption of an anionic dye through ion-exchange membrane adsorber, J. Memb. Sci., 2009, 340, 234-240.

8- M. Hadri, Z. Chaouki, K. Draoui, M. Nawdali, A. Barhounb, H. Valdés, N. Drouiche, H. Zaitan, Adsorption of a cationic dye from aqueous solution using low-cost Moroccan diatomite: Adsorption equilibrium, kinetic and thermodynamic studies, Desalin. Water Treat, 2017, 75, 213-224.

9- $\quad$ N. K. Amin, Removal of reactive dye from aqueous solutions by adsorption onto activated carbons prepared from sugarcane bagasse pith, Desalination, 2008, 223, 152-161.

10- A. R. Shawwa, D. W. Smith, D. C. Sego, Color and chlorinated organics removal from pulp mills wastewater using activated petroleum coke, Water Res., 2001, 35, 745-749.

11- F. Falil, F. Allam, B. Gourich, C. Vial, F. Audonnet, Adsorption of Astrazon Orange G onto natural Moroccan phosphate rock: A mechanistic study, J. Environ. Chem. Eng., 2016, 4, 2556-2564.

12- A. Gil, F. C. C. Assis, S. Albeniz, S. A. Korili, Removal of dyes from wastewaters by adsorption on pillared clays, Chem. Eng. J., 2011, 168, 1032-1040.

13- S. Bentahar, A. Dbik, M. El Khomri, N. El Messaoudi, A. Lacherai, Removal of a cationic dye from aqueous solution by natural clay, Groundw. Sustain. Dev., 2018, 6, 255-262.

14- Y. Yang, S. Han, Q. Fan, S.C. Ugbolue, Nanoclay and modified nanoclay as sorbents for anionic, cationic and nonionic dyes, Text. Res. J., 2005, 75, 622-627.

15- T. Ngulube, J.R. Gumbo, V. Masindi, A. Maity, An update on synthetic dyes adsorption onto 
clay based minerals: a state-of-art review, J. Environ. Manag., 2017, 191, 35-57.

16- J. Chang, J. Ma, Q. Ma, D. Zhang, N. Qiao, M. Hu, H. Ma, Adsorption of methylene blue onto $\mathrm{Fe} 3 \mathrm{O} 4 /$ activated montmorillonite nanocomposite, Appl. Clay Sci., 2016, 119, 132-140.

17- P. Sharma, D.J. Borah, P. Das, M.R. Das, Cationic and anionic dye removal from aqueous solution using montmorillonite clay: evaluation of adsorption parameters and mechanism, Desalin. Water Treat., 2015, 57, 8372-8388.

18- S. Lagergren, Zur theorie der sogenannten gelöster stoffe, Kungliga, Svenska Vetenskapsakademiens. Handlingar 1898, 24(4), 1-39.

19- Y. S. Ho, G. McKay, D. A. J. Wase, C.F. Forster, Study of the sorption of divalent metal ions on to peat, Adsorp. Sci. Technol., 2000, 18, 639-650.

20- I. Langmuir, Adsorption of gases on plain surfaces of glass mica platinum, J. Am. Chem. Soc., 1918, 40(9), 1361-1403.

21- H.M.F. Freundlich, Over the adsorption in solution, Z. Phys. Chem., 1906, 57, 385-470.

22- M.N. Ahmad, R.N. Ram, Removal of basic dye from waste-water using silica as adsorbent, Environ. Pollut., 1992, 77, 79-86.

23- K. Marungrueng, P. Pavasant, Removal of basic dye (Astrazon Blue FGRL) using macroalga Caulerpa lentillifera, J. Environ. Manage., 2006, 78, 268-274

24- B. Karagozoglu a, M. Tasdemir a, E. Demirbas b, M. Kobya, The adsorption of basic dye
(Astrazon Blue FGRL) from aqueous solutions onto sepiolite, fly ash and apricot shell activated carbon: Kinetic and equilibrium studies, J. of Hazard. Mat., 2007, 147, 297-306

25- O. Sözüdoğru, B.A. Fil, R. Boncukcuoğlu, E. Aladağ, S. Kul, Adsorptive removal of cationic (BY2) dye from aqueous solutions onto Turkish clay: isotherm, kinetic, and thermodynamic analysis, Part. Sci. Technol., 2015, 34, 103-111.

26- M. T. Sulak, E. Demirbas, M. Kobya. Removal of Astrazon Yellow 7GL from aqueous solutions by adsorption onto wheat bran, Bioresour. Technol., 2007, 98(1), 2590 -2598

27- I. Chaari, E. Fakhfakh, M. Medhioub, F. Jamoussi, Comparative study on adsorption of cationic and anionic dyes by smectite rich natural clays, J. Mol. Struct., 2019, 1179, 672-677

28- J. Yener, T. Kopac, G. Dogu, T. Dogu, Adsorption of Basic Yellow 28 from aqueous solutions with clinoptilolite and amberlite. J. Colloid Interface Sci., 2006, 294(2), 255-264.

29- M. Turabik, Adsorption of basic dyes from single and binary component systems onto bentonite: Simultaneous analysis of Basic Red 46 and Basic Yellow 28 by first-order derivative spectrophotometric analysis method, J Hazard Mater., 2008, 158(1), 52-64.

30- N. Tekin, A. Şafaklı, D. Bingöl, Process modeling and thermodynamics and kinetics evaluation of Basic Yellow 28 adsorption onto sepiolite, Desalin. Water Treat., 2015, 54(7), 2023-2035. 